\title{
Quality of Chiretta (Swertia chirayita) in Cultivated and Wild Samples Collected from Different Districts of Nepal
}

\author{
Tanka P. Barakoti ${ }^{1}$, Narendra N. Tiwari ${ }^{2}$ and Minoba Yonzon ${ }^{2}$ \\ ${ }^{1}$ Nepal Agricultural Research Council (NARC) \\ Agricultural Research Station, Pakhribas, Dhankuta \\ ${ }^{2}$ Herbs Production and Processing Company Limited (HPPCL) \\ Koteswor, Kathmandu
}

\begin{abstract}
An experiment under the scaling up project of ARS Pakhribas was conducted to identify quality and compare the cultivated and wild Chiraito (Swertia chirayita) samples collected from eastern, central and western regions hill districts during 2004. This work aimed to identify best sites/ districts for quality production of this important medicinal herb through cultivation and conservation for initiating export of value added quality product in a sustainable way. Processed product is cheaper to send the overseas market as the volume and weight are decreased. Quality analysis is necessary to ensure quality standard of international market in the context of WTO. Assessment of the collected samples was done by quantifying the extract content and analyzing bitter principle in the Herbs Production and Processing Company lab, Kathmandu. The result revealed that extract content and bitter principle percent varied depending upon different agro-eco growing conditions and extraction method. Hot extraction gave more extract of the plant than cold percolation method. Wild samples, in general, contained higher bitter principle than cultivated, whereas extract content was higher in cultivated Chiraito. The international market could be better ensured with such study result.
\end{abstract}

Key words: Chiraito, quality analysis, extract, bitter principle

\section{Introduction}

\section{Economic and medicinal value}

Chiretta (Swertia chirayita) is a medically and economically important herb of Nepal. It has historical, ethno-botanical and environmental values as well (Barakoti 2004). The whole plant is bitter, and is used for local healthcare and to manufacture Ayurvedic medicines since time immemorial. Over two dozens of diseases, disorders and ailments are cured by Chiraito. It is a tonic, appetizer, febrifuge, anthelmintic, stomachic, laxative, blood purifier, and has antibiotic property. It is effective against fever, jaundice, gastritis, worms, influenza, diabetes, headache, urinary disorder, etc. Important bio-chemical constituents are: bitter yellow ophelic acid, and two bitter glycosides-chiratin and amarogentin. Chiratin is not a pure substance and amarogentin is a phenol carbonic acid ester, a substance related to gentiopicrin. It is an important source of cash income for traders, collectors, and growers who have been trading this herb since generations. Nepal exports about $50 \%$ of the world's total traded volume of dry product amounting 300 to 450 metric tons per year. Major buyer is India (about $70 \%$ ), China (about $20 \%$ ) and other two dozens of Asian, European, American and African countries. Local use is very low (about $5 \%$ ).

\footnotetext{
Botany

Chiretta belongs to the family Gentianaceae. Thirty species of Swertia have been identified in Nepal, of which 9 species are traded (8 in nominal quantity). All species in Nepal are commonly called Chiraito. The most valuable species is the S. chirayita, (Roxb.ex Fleming) Karsten. The plant is erect with robust stem, branching, normally 0.7-1.5 m tall, herbaceous, biennial, cylindrical stem with large pith, leaves broadly lanceolate, opposite, flowers greenish yellow, many, tinged with purple, in large panicles, capsules egg-
} 
shaped, many light and tiny seeded, and small capsule fruit. Chromosome number: $2 \mathrm{n}=20,24,26$.

\begin{abstract}
Chemistry
Chiretta plants constitute two main intensely bitter principles, Ophelic acid and Chiratin both amorphous and indistinctly crystalline yellow substances. Acceptable level of bitter principle content is above $1.3 \%$, which contains a bitter glycoside amarogentin, numerous tetra oxygenated xanthones including swertinin (7,8- dihydroxy 1,3 dimethoxyxanthone), swertianin (1,7,8-trihydroxy-3-methoxyxanthone), swerchirin (1,8- dihydroxy- 3, 5-dimethoxyxanthone), decussating (1-hydroxy, 2,6,8-trimethoxyxanthone), isobelidifolin (1,6,8-trihydroxy- 4- methoxyxanthone, 1,3,7,8- tetrahydroxyxanthones), 1, 8 - dihydroxy -3 , 7-dimethoxyxanthone, 1- hydroxy- 3,5,8 trimethoxyxanthone, mangiferin $(1,3,6,7$ tetrahydroxyxanthon- $\mathrm{c}_{2}-\mathrm{a}$ - D-glycoside, and several other; triterpenes (luperol, â- amyrin, etc) and monoterpene alkaloids, among others.
\end{abstract}

\section{Distribution and status}

Endemic to the Nepal Himalayas, Swertia chirayita grows in the temperate belt of the mountain region between 1500 to 3000 masl. The most suitable growing altitude is 1800-2700 masl (Barakoti, 2001) and is found in 55 hill and mountain districts. This species flourishes well in the areas with high humidity, long monsoon period, well drained fertile humus, sandy to silt loam acidic soil ( $\mathrm{P}^{\mathrm{H}} 4.7$ to 5.8$)$ under sparsely dense trees. Due to over-harvesting, lack in conservation and cultivation, this species is still in threat as categorized vulnerable by International Union for Conservation of Nature (IUCN), (2000). Therefore sustainability of production and marketing is the major concern along with the dissemination of cultivation technology. Therefore, appropriate quality level should be known and employed for better implication.

\section{Post-harvest and quality}

The quality of Chiretta is not yet standardized along with certification. No any post-harvest practice is undergone for maintaining quality and value addition. Sorting and grading is normally not practiced. Immature and or with weed, disease-infected plants are also mixed. The farmers do not know suitable drying and curing techniques for high quality product. This practice is recently identified (Barakoti 2011). Similarly proper storing and packaging are lacking. Traders and exporters do not follow chopping, pressing and grinding. Unprocessed crude plants are voluminous while sending overseas. Chiraito can be processed through extraction method. If the product could be sent in dust or extract form, export problem via India would not be faced. Market-led product should be produced and traded with acceptable quality standard in the days to come considering WTO requirements. Therefore quality analysis and market survey are necessary to identify the real situation, value addition as well as policy formulation.

\section{Scaling up}

The Hill Agriculture Research Project (HARP) funded research project on "Developing propagation and management techniques for the domestication of Chiraito" was implemented by ARS Pakhribas (by the main author) under Nepal Agricultural Research Council (NARC). It had developed cultivation technologies for domestication, and disseminated through uptake pathways and scaling-up. Gundel et al. (2001) reported that scaling-up aims to provide more quality benefits to more people, over a wider geographical area, more quickly, more equitably and more lastingly. The project entitled "Identification of appropriate scaling-up methodologies for the domestication of Chiraito in Nepal", implemented by NARC, ARS, Pakhribas (led by the project coordinator Dr TP Barakoti), had the purpose of vertical and horizontal scaling up of Chiraito domestication technologies.

\section{Market promotion vs quality}

Marketing is one of the major concerns for agricultural and forest produces in Nepal. Chiraito has been facing low price and demand since 2002 onwards. Marketing problems has been identified as a priority problem in the workshops as well. There is fluctuation of price, one of the reasons of which is the lack of certification and quality standard. Due to exportable commodity, demand from abroad should come continuously. For this, quality of the produce should be improved through processing and value addition. In order to get reasonable price, quality of the produce should be known and the markets need to be promoted. Otherwise farmers cannot expand and continue Chiraito farming. This may interrupt adoption of the recommended technologies. Promotion of local and foreign markets is necessary for the good quality product. 
Tanka P. Barakoti et al./Quality of Chiretta (Swertia chirayita).......

\section{Methodology Selection of collaborating organizations}

For efficient participatory work, three dozens of government agencies and I/NGOs were contacted to identify potential collaborators among the concerned organizations. A list of project activities, in which collaboration was sought, was made available creating awareness on the need of Chiraito domestication for technology scaling-up and waited for two months to receive their response. About ten organizations selected based on their response, views and interest to collaborate in different activities such as questionnaire surveys, workshop organization, and the quality testing. Herbs Production and Processing Company Limited (HPPCL) was selected for quality analysis: extraction, extract and bitter principle determination, etc. Likewise, NGOs: Chiraito Conservation and Development Organization (CCDOfounded by Dr TP Barakoti), at Basantapur, Terhathum and Environment Protection and Development Forum (EPDF), Fungling, Taplejung were selected to manage Chiraito samples.

\section{Sample collection and quality testing}

Wild and cultivated samples of dry Chiraito plants were collected from the Chiraito growing 10 hill districts of eastern, central and western regions. A total of 14 samples@ 2-3 kg were provided to HPPCL by the collaborators: EPDF Taplejung, CCDO Terhathum and HPPCL Kathmandu. Sample collection and delivery was managed by the main author project leader. Extraction was done in the HPPCL lab Koteswar through hot and cold methods for which ethanol 70\% was used as solvent. The samples were analyzed to check the standard, efficacy and safety for marketing. Bitter principle was analyzed through assay of the plant. Extract samples were sent to USA, Europe and Africa for market promotion. Unfortunately, there was no response and feedback about quality from the sample receivers.

\section{Assay}

Two grams of the coarsely powdered sample was boiled with $100 \mathrm{ml}$ of water and $0.5 \mathrm{~g}$ of calcium carbonate for about one hour. Then the extracted boiled sample was devoid repeatedly with boiling water-containing $\mathrm{CaCO}_{3}$ until the last portion of the extraction of bitterness. Then the infusion was concentrated and dissolved that residue in hot alcohol.
Alcohol was removed from the filtrate and took that residue repeatedly with $25,15,15,15,15 \mathrm{ml}$ of hot water. Aqua's extract was then shacked repeatedly with $25,20,15,15$, and $10 \mathrm{ml}$ of ethyl acetate. Finally, ethyl acetate shaking was collected and evaporated, dried and weighed. Weighing was done until the constant weight was observed. Finally, percentage of bitter principle present in the sample was calculated as

$\%$ of Bitter Principle $=\frac{\text { Weight of the residue obtained }}{\text { Weight of sample taken }} \times 100$

\section{Moisture content}

Five gram sample was weighed in a butter paper and dried in an air oven at $80^{\circ} \mathrm{C}$ until the constant weight was observed. Difference in two weighings gave total moisture present.

Extraction was done in the HPPCL laboratory Kathmandu through hot and cold percolation methods. In both methods ethanol $70 \%$ was used as solvent. Besides extraction, the samples were analyzed to check the standard, efficacy and safety for marketing. Therefore quality analysis and chemical analysis were done for the all samples. Chemical analysis consisted of bitter principle and moisture content. Bitter principle was analyzed by doing assay of Chiraito plant.

\section{Technology transfer}

The research work aimed to aware on processing and testing of product sample for the conservation in connection with great medicinal values in a sustainable way and finally to export the best quality product. It was expected from the selected collaborating organizations for effectively dissemination of Chiraito technologies. The strategy identified was effective methods to wider range of people on sharing technological benefit and appropriate mechanism for quality delivery and use of result to grass-root users. The processed resin type produce was sent as sample to UK and USA to know the buyers' view also.

\section{Results and Discussion \\ Extraction and extract}

There was variation among the samples of different locations: in hot extraction- 15.6\% (Sindhupalchok, cultivated) to $22.4 \%$ (Terhathum, cultivated). Similarly, in cold percolation the above samples had $10.0 \%$ to $18.1 \%$ respectively. Extract percent was lower in all 
samples of cold percolation than the hot extraction method.

\section{Bitter principle}

The bitter principle as a main indicator of medical herbs, varied from 0.95 to $2.0 \%$ in the tested samples of Chiraito. Higher bitter principle (2\%) was found from wild Chiraito of 4 locations (Taplejung- Suketar and Phawakhola site, Terhathum- Bhusune-Jiptare and Nuwakot). Pharmacopeial limit of bitter principle is $1.3 \%$. Two other samples also crossed this limit (Dhading- Toplang 1.5\% wild and Sindhupalchok-1.5\% cultivated).

\section{Pharmacological and biological actions}

Chiraito is excellent for fever, malaria, blood purification, worms, skin diseases, sciatica, a gentian substitute, toxic blood, enlarged spleen, and liver, catarrh, intestinal spasm, anemia, indigestion and in diabetes. Some of its xanthones (swertianin, $1-3,7,8$ - tetrahydroxyxanthone and 1, 8 dihydroxy3, 7 - dimethoxyxanthones) have been claimed to have anti-tuberculosis activities. Amarogentin is hepatoprotective in vitro against carbon tetrachloride toxicity. Swerchirin is anti malarial. It has significant anti-inflammatory activity in various acute, sub-acute and chronic experimental models with rodents of a total benzene extract. Whole plant of $S$. chirayita is useful as hypoglycemic effect.

\section{Extraction}

Extraction of Chiraito plant was done by both hot and cold methods as:

Hot extraction. In hot extraction method comminuted samples were placed in a round bottomed flask with solvent (ethanol 70\%) and extracted out active ingredients in a heating mantle at the temperature of $100^{\circ} \mathrm{C}$. Extraction was done for three times and concentrated the solvent at $60-70^{\circ} \mathrm{C}$ and obtained a syrupy mixture.

Cold extraction. In cold extraction method samples were extracted out with solvent (ethanol 70\%) without giving heat. Left the sample and solvent mixture for 24 hours and percolated. Maceration was done for three times with same quantity of solvent. Percolated solvent was concentrated at $60-70^{\circ} \mathrm{C}$ and obtained a syrupy mixture.

\section{Quality analysis}

Quality of any product should be checked for standard, efficacy and safety to be marketed. According to GMP to ensure the quality of any product, quality control is very essential. It is done by (1) checking the quality of raw materials and processing methods and (2) checking the quality of finished product.

\section{Chemical analysis}

Chemical analysis consists of bitter principle and moisture content. Bitter principle was analyzed by doing assay of Chiraito plant.

Table 1. Extract content in S.chirayita samples collected from different agro-eco zone districts

\begin{tabular}{c|l|c|c}
\hline Serial No. & Sample collected district (village) & $\begin{array}{c}\text { Hot extraction, } \\
\text { (\% of extract) }\end{array}$ & $\begin{array}{c}\text { Cold percolation, } \\
\text { (\% of extract) }\end{array}$ \\
\hline 1 & Dhading (Toplang), wild & 18.00 & 15.50 \\
2 & Dhading (Likhu), wild & 17.00 & 13.20 \\
3 & Nuwakot (NA), wild & 17.96 & 13.20 \\
4 & Nuwakot (NA), wild & 17.96 & 10.00 \\
5 & Sindhupalchok, cultivated & 15.55 & 17.02 \\
6 & Sankhuwasabha (Okhre), cultivated & 20.30 & 18.06 \\
7 & Terhathum (Morahang), cultivated & 22.44 & 18.54 \\
8 & Terhathum(Bhusune-Jiptare CF), wild & 19.80 & 12.26 \\
9 & Terathum (Basantaput), wild & 16.80 & 16.96 \\
10 & Dhankuta (ARS Pakhribas), cultivated & 19.00 & 14.86 \\
11 & Ilam (NA), wild & 17.71 & 17.42 \\
12 & Taplejung (Suketar), wild & 20.76 & 15.85 \\
13 & Taplejung (Phawakhola), wild & 16.72 & 13.30 \\
14 & Taplejung (Lelep), wild & 18.26 & \\
\hline
\end{tabular}

Of the 14 samples included in this study, highest percentage of extract through hot percolation method was obtained from Morahang (20.76\%), Terhathum and low percentage (15.55\%) was from Sindhupalchok. 
Tanka P. Barakoti et al./Quality of Chiretta (Swertia chirayita).......

Both the samples were from cultivated plot. High percentage of extract was obtained by cold percolation method from Terathum, Bhusune-Jiptare community forest (18.06\%) and low percentage (12.26\%) from Basantapur, Terathum collected from wild. Similarly, high bitter principle (2 \%) was analyzed from four district areas: Nuwakot, Sankhuwasabha (Okhre), Terathum (Bhusune-Jiptare), and Taplejung (Suketar) and lowest percentage $(0.95 \%)$ was analyzed from Dhading (Likhu)

Table 2. Bitter principle in S.chirayita samples collected from different agr-eco zone districts

\begin{tabular}{c|l|c|c}
\hline Serial No. & Sample collected district & Moisture content (\%) & Bitter principle (\%) \\
\hline 1 & Dhading (Toplang, wild) & 9.41 & 1.5 \\
2 & Dhading (Likhu, wild) & 9.71 & 0.9 \\
3 & Nuwakot (wild) & 10.33 & 2.0 \\
4 & Nuwakot (wild) & 10.33 & 2.0 \\
5 & Sindhupalchoki (cultivated) & 9.23 & 1.5 \\
6 & Sankhuwasabha (Okhre, cultivated) & 9.91 & 1.0 \\
7 & Terhathum (Morahang, cultivated & 9.50 & 1.0 \\
8 & Terhathum (Bhusune-Jiptare CF, wild) & 9.60 & 2.0 \\
9 & Terhathum (Basantaput, wild) & 8.70 & 1.0 \\
10 & Dhankuta (ARS Pakhribas, cultivated) & 8.86 & 1.0 \\
11 & Ilam (wild) & 10.03 & 2.0 \\
12 & Taplejung (Suketar, wild) & 9.30 & 2.0 \\
13 & Taplejung (Phawakhola, wild) & 8.43 & 1.0 \\
14 & Taplejung (Lelep, wild) & 12.00 & \\
\hline
\end{tabular}

Pharmacopeial limit I.P. for all samples is $1.3 \%$.

The result of extraction and analysis of S. chirayita plant collected from different locations showed that the best quality based on its bitter principle would be valuable information for the selection and cultivation of Chiraito. The competitive market would be better challenged with such study and be fruitful in utilizing local natural resources.

From extraction point of view extract percent is higher in cultivated plant than wild; however, from quality point of view wild specimens constrain high bitter principal than cultivated ones.

- The extract percent and bitter principle of Chiraito vary depending on different growing conditions.

- Hot extraction can give more extract of Chiraito plant than cold percolation method.

- Wild specimen contains in general higher percent of bitter principle than cultivated.

- Extraction and quality analysis of Chiraito is necessary to ensure quality standard for international market.

- Analysis of Chiraito plants from different locations should be done for wild and cultivated simultaneously.

- The growers and traders should check the quality of Chiraito through analysis before selling outside.
The results are from limited samples which might have different maturity level when harvested. Therefore, an increased number of samples checking their maturity is suggested to analyze for verification and validation of the results.

\section{Acknowledgements}

The authors would like to express their gratitude to the Hill Agriculture Research Project team led by Dr SB Mathema for financial support to conduct the experiment. The Station Chief Mr. P.L. Karna and support staff of ARS Pakhribas, NARC and all the collaborators (mainly Mr. C.P. Bhattarai, EPDF, Mr H. Khadka, CCDO, and Mr S. Subedi, HPPCL) and the farmers are thankful for their help in sample collection and delivery. Likewise, they would like to express sincere thanks to the team members of HPPCL (Mr. J.M. Bajracharya, Mr. S. Subedi, Mr. P.K. Maharjan, Mrs. H. Chapagain, Mr K. Shrestha, and Mrs. G. Shrestha) for technical help in analyzing the samples at lab. Finally, the authors would like to thank the coordinator of Chiraito scaling up project, Dr. T.P Barakoti from Agricultural Research Station Pakharibas for collaborating and organizing implement this activity and supplying the samples in time. 


\section{References}

Barakoti, T.P. 2004. Attempts made for domestication conservation and sustainable development of Chiretta (Swertia chirayita), A compilation Report, NARC, ARS Pakhribas, Dhankuta, Nepal (P. No.x+152).

Barakoti, T. P. 2002. Commercial Cultivation and Production Management of Chiraito: Scheme guide (in Nepali). ARS Pakhribas, Dhankuta, Nepal.

Barakoti, T.P, 2000. Chiraito to Boost Income. The Kathmandu Post / Sunday Post, Dec., 17, 2000, Kathmandu.

Barakoti, T P. Developing Propagation and Management Techniques for the Domestication of Chiraito (Swertia chirayita), Annual Report 2000, ARS, Pakhribas, Dhankuta, Nepal.

Daniggelis, E.K. 1996. Swertia chirayita can supplement rural income in Nepal. Banko Janakari, Vol.6, No. 12, Kathmandu, Nepal.
Encyclopedia of Common Natural Ingredients Used in Food Drugs and Cosmetics

Gundel, S., J. Hancock and S. Anderson. 2001. Scaling up strategies for research in natural resources management: a comparative review, NRI, UK. 61 p.

IUCN. 2000. National Register of Medicinal Plants. IUCN, HMG/N, MFSC, Nepal 161 p.

Joshi, K.K. and S.D. Joshi. 2001. Genetic Heritage of Medicinal and Aromatic Plants of Nepal Himalayas, Buddha Academic Publishers and Distributors Pvt. Ltd. Kathmandu Nepal. 239 p.

Quality Standards of Ayurvedic Crude Drugs. 2003. A.K. Gupta, Neeraj Tandon and Madhu Sharma (eds.), Vol. 1, 2003. 2362 pp, ICMR, New Delhi, India.

Wallis, T.E. 1967. Text book of Pharmacognosy, $5^{\text {th }}$ Edition, xi+652 pp, London, England. 